\title{
Poverty and Perseverance: The Jesuit Mission of Isfahan and Shamakhi in Late Safavid Iran
}

\section{Pobreza y perseverancia: La misión jesuita de Isfahán y Shamakhi en el Irán Safaví tardío}

\author{
Rudi Matthee \\ University of Delaware
}

This essay considers the presence and activities of the Jesuits in early modern Iran, a topic that, to date, has received little attention in English-language scholarship. It examines their motives for wanting to establish a permanent mission in Safavid territory in the mid-seventeenth century - a desire to bring Iran's Gregorian Armenians under papal jurisdiction and, in part, their search for an overland route to India and China free from Portuguese influence - and discusses these in the context of Iranian concerns and interests. The study's particular focus is the role of French and Polish Jesuits in the establishment of a mission in Isfahan and the subsequent creation of an outpost in Shamakhi, located in the Safavid-held part of the Caucasus, on the trade route between Iran and Russia. It concludes by evaluating their (meager) accomplishments despite perseverance in the face of poverty and loneliness.

Key words: Missionaries; Jesuits; Iran (Persia); Safavid Empire; Armenians.
Este trabajo estudia la presencia y las actividades jesuitas en Irán a comienzos de la época moderna, tema que hasta ahora ha recibido poca atención por parte de la investigación anglosajona. Se examinan algunos de los motivos que tuvieron los jesuitas por establecer una misión permanente en territorio Safaví a mediados del siglo XVII: el deseo de integrar a los Armenios Gregorianos de Irán bajo el dominio papal y buscar una ruta terrestre hacia India y China libre de influencia portuguesa. Estos motivos son discutidos en este trabajo teniendo en cuenta, sobre todo, los intereses y preocupaciones iraníes. Este estudio está dedicado, sobre todo, a estudiar el papel que jugaron los jesuitas franceses y polacos en el establecimiento de una misión en Isfahán, así como la posterior creación de un puesto en Shamakhi, situado en la parte Safaví del Cáucaso, en la ruta comercial entre Irán y Rusia. Este trabajo concluye con una evaluación de los exiguos logros obtenidos en esas misiones, a pesar de la perseverancia de sus actores, teniendo en cuenta la pobreza y soledad que encontraron.

Palabras clave: Misioneros; Jesuitas; Irán (Persia); Imperio Safaví; Armenios. 


\section{Introduction}

Modern scholarship on the European missionary presence in early modern Iran has mostly focused on the activities of the representatives of Spanish and Portuguese orders in the period of Shah 'Abbas I (r. 1587-1629), the formidable Safavid ruler whose reign marks the height of Iran's interaction with the West in early modern times. The late Roberto Gulbenkian has published a number of important studies on relations between the Iberian missionaries and the Iranian-Armenian community of New Julfa, which was a particular target in the missionary effort to bring Eastern Christians under papal control. And Father Carlos Alonso O.S.A. in the past half century has given us numerous books and source-based articles on the activities of especially the Augustinians in Safavid Iran, the Persian Gulf and Portuguese India. A recent monograph on the Augustinians in the Safavid realm not only brings this research together for the Anglophone reader, but represents a further step in the study of the presence and operations of the Spanish and Portuguese fathers during Shah 'Abbas's reign. ${ }^{1}$

In the period following the death of Shah 'Abbas in early 1629, the importance of the Iberian men of the cloth markedly diminished and French and, to a lesser extent, Polish friars became the leading representatives of the missionary effort in the Safavid realm. The arrival of the Capuchins in Iran in 1628 and the subsequent foundation of their mission are the best examples of a new and active role of French fathers in this endeavor. The first Jesuit initiative, which was launched some two decades later, was spearheaded by the French, too, but soon acquired a lasting Polish component as well.

Modern scholars have not overlooked the French missionary record in Iran. Francis Richard's biography-cum study of the most remarkable of the French Capuchins, Raphaël du Mans, is a landmark achievement in this regard. ${ }^{2}$ The Jesuits, too, have received some attention, most notably in articles by Wilson, Krzyszkowski, and Zimmel. ${ }^{3}$ This essay

${ }^{1}$ See Gulbenkian, Estudios Históricos. The list of Alonso's publications is too long to enumerate here; an overview until c. 2000 can be found in Flannery, Mission of the Portuguese Augustinians, pp. 255-256.

${ }^{2}$ See Richard, (ed.), Raphaël du Mans.

${ }^{3}$ Wilson, "Mission of the Fathers"; Krzyszkowski, "Entre Varsovie et Ispahan; Zimmel, "Vorgeschichte und Gründung"; and Richard, "Le Père Aimé Chézaud." For an overview, see Matthee, "Jesuits in Safavid Persia." 
uses these studies in addition to material from primary sources, including archival ones, to discuss the activities of the Jesuits in Iran, focusing on their reasons and motivations for wanting to establish a permanent mission in Safavid territory in the mid-seventeenth century. It looks at these in the context of the political and religious concerns and interests of the Iranians - administrators as well as religious authorities, state actors and non-state actors - which have received scant attention by scholars relatively unfamiliar with Safavid history who have often approached the issue exclusively from an "Iberian" or a "missionaryChristian" angle. The Safavids at that time had made peace with the Ottomans, and diplomatic contacts between Iran and Europe no longer automatically centered on creating a cordon sanitaire around the Turks. The elders of the Gregorian-Armenian community of New Julfa, meanwhile, mounted fierce opposition to the missionary attempts to bring them under papal jurisdiction - precisely one of the objectives of the Jesuit project in the Safavid state. Their other aim was a desire to establish a base on the (projected) land route to China as an alternative to the maritime route, which had long been controlled by the Portuguese but had become problematic with the fall of Malacca to the Dutch in 1641. Isfahan was the initial target of this project, but in time the Jesuit fathers also acquired a foothold in the Caucasus.

The second part of the essay discusses this northern foray, focusing on the Jesuit presence in Shamakhi, the capital of the region of Shirvan and currently located in the Republic of Azerbaijan, where, partly for the same reason of creating a relay station on the land route to Central Asia and beyond, they established a small mission in the 1680s. In Shamakhi, as in Isfahan, the Jesuits lived in utter poverty, their accomplishments were few, and the prospects for future success were dim. Yet, as will be seen, they persevered, suggesting that they were above all driven by religious zeal and devotion in their pursuit of salvation by way of evangelizing among the peoples of Asia. ${ }^{4}$

\footnotetext{
${ }^{4}$ For a reiteration of this focus on religious piety and zeal in the face of the modern tendency to emphasize the educational and scientific contribution of the Jesuits, see Clossey, Salvation and Globalization, pp. 246-247.
} 


\section{The Jesuit Mission in Safavid Iran}

The later prominence of the Augustinians and the Carmelites in Iran notwithstanding, the Portuguese Jesuits were the first to enter the Persian Gulf in the mid-sixteenth century, operating from their Asian base in Goa and under the auspices of the Padroado, the Portuguese government-funded institution that oversaw Lusitanian overseas dioceses. At that point the Jesuits remained confined to the Portuguese-held isle of Hormuz, where they resided for a brief two decades before retreating to India in 1568 , having made no lasting impact by way of conversion or educational achievement. ${ }^{5}$

Some thirty years later, their appetite whetted by rumors about Shah 'Abbas's Christian inclinations, the Jesuits were ready and eager to enter the Iranian mainland. Pope Clement VIII (r. 1592-1605) initially gave his blessing to Jesuit leadership in this initiative. However, owing to the intervention of the Augustinian archbishop of Braga and his relative, Aleixo de Meneses, the bishop of Goa who promised financial support for an Augustinian foray into Safavid territory, the task eventually fell to the latter. Arriving in 1602, the Augustinians thus were the first to establish a convent in the Safavid capital, shortly to be joined by the Carmelites. The Jesuits would only follow in the 1640s, not just trailing their Iberian rivals but even the French Capuchins, who in 1628 were given permission to build a convent in Isfahan.

By the time the Jesuits arrived in Isfahan, the political landscape had changed rather dramatically, in Iran as well as in Europe. For all we know, Shah 'Abbas I harbored few illusions about the chances of actually forming a grand anti-Ottoman alliance with the Christian nations. Yet, expansive in his approach to geopolitics and keen to exploit its opportunities, he played an ingenuous game around the theme of joining an anti-Ottoman alliance with those who came to his realm to negotiate its terms. His immediate successors, Shah Safi I (r. 1629-42) and Shah 'Abbas II (r. 1642-66), were far less inclined to entertain relations with far-off powers for uncertain gain. The definitive change in Iranian foreign policy came in 1639, when the Safavids, having lost Mesopotamia, concluded the so-called Peace of Zohab (or Qasr-e Shirin) with the Ottomans, ending almost half a century and a half of intermittent warfare

\footnotetext{
${ }^{5}$ For this, see Alonso Roma, "Gaspar Barzeo."
} 
with their archenemies. Zohab lessened the urgency for the Safavids of finding allies against the Turks and thus reduced the importance of maintaining diplomatic relations with Christian powers and, with that, the role of European diplomats including missionaries in Iran. ${ }^{6}$

In Europe, meanwhile, the center of gravity of the missionary endeavor in Asia had shifted, first from Madrid and Lisbon toward Rome, then to France. In the course of the seventeenth century, it would further tilts to France. Pope Gregory XV in 1622 created the Sacra Congregatio de Propaganda Fide. This institution, designed to take the lead in propagating the faith around the world, broke the Iberian monopoly on missions to the East. Indeed, its planning in the interior of Asia was in part conceived in competition with Portuguese activities in maritime Asia. In Iran, however, its efforts suffered a setback when the Discalced Carmelite Juan Tadeo de San Elisio, who had gained a great deal of experience during more than two decades of living in Iran, died a year after the Propaganda Fide appointed him as the first bishop of Isfahan. His successor, Timotheus Perez, knowing neither Persian nor Turkish, asked to be excused from going to Iran and instead settled in his native Spain. ${ }^{7}$ With Spain in decline, its role as Europe's leading Catholic power devolved on France in a process that would culminate under Louis XIV (r. 1643-1715). Unlike the other Catholic powers of Europe, whose foreign policy was informed by an ardent desire to sideline and neutralize the Ottomans, France was effectively aligned with the Turks in its rivalry with the Habsburg state. These circumstances enabled Paris to expand its influence throughout Ottoman territory and beyond. Missionary activity under the auspices (and with the financial support) of the French monarch became an integral part of this thrust, beginning with the Capitulations of 1604, which made Henry IV (r. 1589-1610) the protector of the sacred Christian sites of Palestine, of Western pilgrims visiting the Holy Land, and of the indigenous Christians of the Levant. Louis XIII (r. 1610-43) continued France's missionary zeal, facilitating the dispatch of especially Capuchin missions to various parts of the Ottoman Empire and Iran in the 1620s. ${ }^{8}$ It is equally as vis-

${ }^{6}$ For this, see Matthee, Persia in Crisis, esp. pp. 118-121.

${ }^{7}$ Anon. [Chick] (ed.), Chronicle of the Carmelites, pp 340-341; Metzler, "Nicht erfüllte Hoffnungen," pp. 688-689.

${ }^{8}$ Vaumas, Lettres et documents du Père Joseph, p. 20. 
ible in the French prevalence in subsequent Jesuit initiatives in the Middle East.

It is in this context that the Jesuits returned to Iran, establishing a lasting presence in the 1650 s after an initial, failed attempt to found a mission in Isfahan a decade earlier. The original initiative, begun in 1643, was launched from Aleppo, where the Jesuits had arrived in 1625 , and was part of a two-pronged project, to create a base on the land route to China and to be able to work among the Armenians of New Julfa. ${ }^{9}$ The person initially chosen for this first mission was Father Aimé (Amatus) Chézaud (1604-64), who at the time resided in Aleppo where he had become acquainted with Muslim and Armenian Iranians. Yet the exploration of opportunities in Iran was eventually entrusted to Father P. Franciscus Rigordi (1609-79), also French in origin and also present in Aleppo. Rigordi arrived in Isfahan in January 1646 but left for India within weeks after his arrival, forced to depart for the Persian Gulf so as not to miss the monsoon-determined shipping season. ${ }^{10}$ He returned to Isfahan a year later. Assisted by the prior of the resident Carmelites and through the mediation of a Flemish/Polish Dominican by the name of Antonio Fiandrini a.k.a. Petrovski who had come to Isfahan as a member of a Polish delegation, Rigordi in late 1647 managed to obtain a decree from Shah 'Abbas II allowing for the purchase of a plot of land and the construction of a house in the Safavid capital. In return, Rigordi promised Safavid grand vizier Khalifa Soltan (in office 1645-54) to seek political and commercial advantage with the French crown upon his return to Europe. ${ }^{11}$

${ }^{9}$ The Jesuits arrived in Aleppo in 1625 but were expelled and forced to leave later that same year. They only managed to return two years later. See Vissière, (eds.), Lettres édifiantes et curieuses, pp. 76-82; and El-Mudarris and Salmon, Le consulat de France à Alep, p. 23. For the China connection, also see Avril, Voyages, p. 156.

${ }^{10}$ The annual shipping season between Bandar 'Abbas and India ran from September to March.

${ }^{11}$ Rigordi, Peregrinationes Apostolica, pp. 9ff; Zimmel, "Vorgeschichte und Gründung," p. 7; Richard (ed.), Raphaël du Mans, 2:207ff. Petrovski was originally Flemish, judging by his original name, Antonio Fiandrese. He had assumed the leadership of the Polish delegation after the original head of the mission, Ilicz, had died in Isfahan. Fiandrese's account of his experience in Iran is contained in a letter from 28 March 1649, in Berchet, (ed.), La repubblica di Venezia e la Persia, pp. 218-225. He is clearly the same person as the Antonio von Flanderen mentioned in Eszer, "Giovanni Giuliani di Lucca," pp. 411-414, as the one who was supposed to accompany Di Lucca to the Crimea in 1634. Thanks to Natalia Królikowska for bringing this to my attention. 
Less than two weeks after receiving the shah's decree, Rigordi left Iran again and set out on his return trip to Europe, to report on his achievements, to consult about future initiatives, and to solicit funds for these. With the roads through Ottoman lands deemed too dangerous and a new Safavid-Ottoman war imminent, he chose to take the northern route. Accompanying the aforementioned Father Fiandrini/Petrovski, he first traveled to Shamakhi in the Caucasus, where he stayed for some five months, presumably to wait out the Russian winter. In the spring of 1648 he resumed his journey, traveling to Moscow and thence to Krakow in Poland. From Poland he went on to Vienna, where Emperor Ferdinand III received him in audience. He next traveled to Graz, where he stayed at the Jesuit College. Among its students he managed to create great enthusiasm for the idea of creating a mission in Iran. In early 1649 he reached Rome, where he briefed Pope Innocent $\mathrm{X}$ on his experience in the realm of the shah. Rigordi would eventually return to France, where he solicited additional funds for the Iranian mission. ${ }^{12}$

Shortly after Rigordi left Rome, another globetrotting Jesuit, Father Alexandre de Rhodes (1591-1660), arrived in the Eternal City. De Rhodes, having earned his stripes in the missions of Japan and Vietnam, became the next advocate of a Jesuit mission in Iran, the country he had passed through in 1648, on his way back from the Far East. Pope Innocent $\mathrm{X}$ and the Curia as well as the leadership of the Propaganda Fide were taken with the idea of a permanent mission in Isfahan, and counted on De Rhodes to help them break the power of the Portuguese Padroado, which they had long viewed as an obstacle to future missionary expansion in maritime Asia. ${ }^{13}$ De Rhodes likely presented Isfahan as an especially attractive target by pointing out both its large Armenian community and its role as a nodal point in the Asian caravan network, making it a useful future relay station on the long overland road to India and China, located beyond Portuguese influence. De

12 Rigordi, Peregrinationes, 9ff.; Wilson, "Mission of the Fathers"; Zimmel, "Vorgeschichte und Gründung," pp. 7-9; and, with extensive information about the projected land route to China, Idem, "Bernhard Diestel"; vol. 2, pp. 882-884.

${ }^{13}$ The stipulation that all missionaries bound for Asia had to sail under Portuguese auspices and depart from Lisbon was tightened during the so-called Portuguese Restoration, coinciding with the reign of Kong John IV (1640-56). See Clossey, Salvation and Globalization, pp. 154-159. 
Rhodes was put in charge of the mission, but since his presence was momentarily needed in Europe, the task of spearheading and running it until his arrival fell to Rigordi and the aforementioned Chézaud.

Rigordi and Chézaud are said to have arrived in Isfahan in early $1652 .{ }^{14}$ The reception at the Safavid court was cordial thanks to a letter of recommendation from Louis XIV and the assistance the Jesuits received from Mohammad Beg, the nazer, supervisor of the royal household. The latter was a great admirer of European science and technology, and in addition was let in on the promises Rigordi and Chézaud had brought with them, the most important of which was that the French king would send a large army to conquer Istanbul, which would divert the Ottoman war machine and enable the Iranian to organize an expedition with the aim of seizing Qandahar from the Mughals. When the fathers also divulged that Louis XIV intended to propose that Anne Marie Louise Henriette d'Orleans, the duchess of Montpensier, would become the shah's future wife, he was received in audience by 'Abbas II. The result of the encounter was a handsome present as well as the assurance that the Jesuits could open missions in Julfa, Tabriz and Shiraz. Rigordi thereupon left Iran and went back to France, traveling via Baghdad and Aleppo. According to Du Mans, he never presented the shah's response to Louis XIV's messages to the latter. ${ }^{15}$

Two years later, Bernhard Diestel, one of the Jesuits inspired by Rigordi when the latter visited Graz, arrived in Iran and observed how the fledgling mission, having encountered resistance from various unnamed Europeans as well as from existing Christian missions, operated in an atmosphere of antagonism and recrimination. The Jesuits themselves appear to have been partly responsible for these conditions. With their habitual air of superiority and their legendary energy, they quickly found themselves in competition with the Capuchins. Far less respectful of the local Christians than the Capuchins, and rather aggressive in their preaching methods, they seem to have offended the local Armenian community of New Julfa as well, incurring the enmity of its elders. The latter, operating in a stressful domestic climate marked by mounting pressure on Iran's non-Shi i population, routinely colluded with

${ }^{14}$ Wilson, "Mission of the Fathers," p. 686.

${ }^{15}$ Richard (ed.), Raphaël du Mans, vol. 2, pp. 211-215. 
secular authorities suspicious of missionary activities to make the life of the European men of the cloth difficult. ${ }^{16}$

Squabbles growing out of intra-Armenian divisions played a role in the prevailing tensions as well. Competition between the diocese of New Julfa and the patriarchate of Echmiadzin in Armenia proper negatively affected the issue of ecclesiastical authority and jurisdiction, and much bad blood existed between the members of the dominant Gregorian branch, called Schismatics by the missionaries, and the smaller Catholic community. The Gregorian-Armenians had long resisted European missionary attempts to bring their kin under papal jurisdiction. Their animosity became more acute with the appointment as Primate of New Julfa of Dawit (David) Julayeci in 1652. Dawit, who was intolerant of Catholics to the point of refusing them the sacraments, wrote letters to the Safavid queen-mother, the patron of New Julfa, arguing that the missionaries had come to convert Muslims to the Christian faith. His ill will vis-à-vis the Jesuit manifested itself in more direct ways as well. Armed with the royal decree, Chézaud went out to find housing in New Julfa. He temporarily found lodging in the residence of the town's Armenian kalantar (head of communal affairs), Sarfraz, who was well disposed toward the Catholic faith. But he quickly ran into opposition from the Gregorian community. Dawit, resentful of the outside intrusion, soon ordered this official to evict his guests. He also forbade any other Armenians from renting to the Jesuits, forcing the latter to accept the hospitality of the resident Carmelites. Chézaud refused to leave New Julfa though, arguing that, as long as the Capuchins were allowed to stay, he would not move. ${ }^{17}$

The Julfans thereupon sent one of their own, a certain Yakobchan, to Mohammad Beg, who had meanwhile been appointed grand vizier, to complain about the behavior of the Jesuits. Accusing them of having come to Iran to convert Muslims to Christianity, he asked for their expulsion from New Julfa. Du Mans recounts how Mohammad Beg, feeling deceived by the Jesuits and their promises, turned to the shah with the request not to allow them to settle in New Julfa until Rigordi's return to Iran and the fulfillment of the commitments he had made in

${ }^{16}$ Ibid., vol. 1, p. 44. For the anti-Armenian measures, see Matthee, Persia in Crisis, pp. 45, 185-186.

${ }^{17}$ Richard (ed.), Raphaël du Mans, vol. 2, pp. 215-217; Ghougassian, Emergence of the Armenian Diocese, p. 294. 
1646. This led to the proclamation of a royal decree, farman, forbidding the building of Christian houses of worship and in particular the construction of a Jesuit one in New Julfa, followed by the ejection of all missionaries from the town in the autumn of 1654. Unsurprisingly, the Capuchins in particular seem to have held the Jesuits responsible for these measures. ${ }^{18}$

These precarious conditions made Chézaud decide to send Diestel to Europe, to report about the Jesuit experience in Isfahan, to collect funds and to make a case for the suitability of Isfahan as a launching pad for the establishment of an overland route to China. Diestel first went to Rome, arriving in early 1655, with a letter for the General of the Jesuit Order, P. Nickel, containing an extensive report about the state of the mission in Iran. He informed Nickel that it would be relatively easy to travel from Isfahan to Samarqand in Central Asia, from where the Great Wall of China could be reached within a reasonable amount of time. ${ }^{19}$ Poland, too, was on his itinerary. There, Diestel was to solicit money as well as letters of recommendation from King John II Casimir (r. 1648-68). He also was to ask the monarch to intervene in the crisis by threatening the Armenian residents of his country with counter measures if their coreligionists did not stop harassing the Jesuits in Isfahan. Arriving in Warsaw sometime in late 1655, Diestel presumably met John Casimir and his energetic wife, Louise Marie de Gonzaga Nevers, and received money, letters for the shah and promises of intervention with the Armenian clerical hierarchy. ${ }^{20}$

The Polish connection was not new. Diplomatic relations between the Polish court and the Safavid state go back to the early sixteenth century. ${ }^{21}$ Polish missionaries had been among the European men of the cloth visiting the Safavid state since 1604; Rigordi had arrived in Iran with a recommendation from a Polish envoy by the name of Jerzy Ilicz; and upon the latter's death in 1647, the aforementioned Father Fiandrini/Petrovski had been one of Chézaud's supporters. As for John

${ }^{18}$ Richard (ed.), Raphaël du Mans, vol. 2, pp. 215-218; Anon. [Chick] (ed.), Chronicle of the Carmelites, pp. 1074-1075; Ghougassian, Emergence of the Armenian Diocese, pp. 139-141, 278-279; Tokatlian, Kalantars, p. 85; and, for the larger political context, Matthee, Persia in Crisis, pp. 189-191.

${ }^{19}$ Zimmel, "Bemühungen," p. 103.

${ }^{20}$ Zimmel, "Bernhard Diestel," p. 886.

${ }^{21}$ Krzyszkowski, “Entre Varsovie et Ispahan,” p. 85. 
II Casimir, he had been a Jesuit himself before he mounted the throne in 1648 (and he would take on the vows again after he abdicated two decades later). Like her husband, the originally French Louise Marie de Gonzaga Nevers enthusiastically supported the Jesuit effort in Iran. For this purpose she had established a fund to which many Polish courtiers contributed, earning her the honorific title of founder of the Jesuit mission in Persia. ${ }^{22}$

In mid-December 1656 Diestel, accompanied by Father Johann Gueber S. J., and armed with letters from various European monarchs and some gifts for the shah, returned to Isfahan, where he joined a mission that, with the arrival of De Rhodes a year earlier and the presence of some Polish friars, now consisted of five men. On 26 December, the Jesuits were received in audience by Shah `Abbas II. The gifts they presented proved to be meager, though, and so did little to impress the Iranians. For unknown reasons only Diestel was invited to represent the Jesuits. Inexperienced, he missed his opportunity to present his letters of introduction to the Safavid ruler. ${ }^{23}$

Not all was tension and stress for the Jesuits. With the assistance of Chapelle de Han, a French engineer and entrepreneur with some standing at the court, they gained access to grand vizier Mohammad Beg. ${ }^{24}$ The protection this acquaintance entailed shielded the Jesuits from the continuing hostility of their adversaries, Shi' $i$ clerics as well as Gregorian-Armenian elders. The fathers soon came to appreciate the openness of the Iranian Muslim elite, their curiosity and willingness to debate even sensitive religious matters. After a misunderstanding involving the possession and alleged desecration of a Qur'an by the missionaries had been solved, Chézaud became a regular guest at the grand vizier's residence, invited to participate in disputations with Iran's Shi 'i clerics about vexing questions such as the Trinity and the nature of prophecy. A model Jesuit intellectual, he also wrote a great deal, treatises on mathematics and polemical works on the Gospels, and the di-

${ }^{22}$ Zimmel, "Bernhard Diestel," p. 886; and Idem "Vorgeschichte und Gründung," pp. 16-17. Rigordi in the afterword to his book thanks Louise Marie for the generosity with which she contributed to "bringing the light of the Gospel to the court of Persia." See Rigordi, Peregrationes, pp. 69-70. For her prominence in the politics of John Casimir's reign, see Frost, "The Ethiopian and the Elephant?"

${ }^{23}$ Zimmel, "Vorgeschichte und Gründung," pp. 19-20.

${ }^{24}$ It was Chapelle de Han who advised the court about the exploitation of precious metal mines in the country. See Matthee, "Mohammad Beg," p. 26. 
vinity of Christ, some of which he presented to the Safavid grand vizier as well. ${ }^{25} \mathrm{In}$ sum, Chézaud formed a link in a long chain of participants in a Muslim-Christian polemic going back to Jerome Xavier S. J. at the court of Sultan Akbar in India at the turn of the seventeenth century. ${ }^{26}$

With Mohammad Beg's assistance the Jesuits eventually managed to move from an inconvenient location outside the city by purchasing a small but serviceable house in an attractive neighborhood, not far from the royal palace. ${ }^{27} \mathrm{At}$ an unspecified later date they appear to have sold this small residence, to buy a plot of land in New Julfa, a garden where they would build a small church and convent. ${ }^{28}$ By the early 1660s they were established in the Armenian quarter of the Safavid capital, with a house and a chapel. P. Mercier, who succeeded Chézaud after the latter's death in 1664, also managed to open a small school catering to Armenian children. ${ }^{29}$ Otherwise, Isfahan functioned as a meeting point for traveling missionaries and a relay station for Jesuit postal communication. Its projected role as an outpost for forays into Central Asia and beyond had not proceeded as planned, however. Following Diestel's recommendation to the Roman authorities with regard to the feasibility of pursuing the China connection, General Nickel had ordered an expedition into Central Asia for 1656, to be headed by Diestel and Grueber. Yet the two fathers initially were prevented from traveling east by the outbreak of an intra-Uzbek war that disrupted communications through northern Afghanistan. A second chance came when the war ended and one of the contestants, 'Abd al- 'Aziz, the ruler of Balkh, sent an envoy named Qolum Hajji to Isfahan. The latter, interested in Western mathematics, invited the Jesuits to accompany him back to Balkh. ${ }^{30}$ Chézaud accepted the invitation and, with a lay brother

${ }^{25}$ Richard, "Le Père Aimé Chézaud," pp. 469ff.

${ }^{26}$ Flannery, Mission of the Portuguese Augustinians, pp. 102-105.

${ }^{27}$ De Rhodes, Relation, pp. 46ff., 82-85. Chézaud also made an impression on Mohammad Beg's nephew, presumably Budaq Beg, a young man who, reportedly fascinated with Western science, liked to sit down with Chézaud and learn from him.

${ }^{28}$ Tavernier, Les six voyages, vol. 1, p. 469. The time and circumstances of this move from Isfahan to New Julfa remain unclear. See Galdieri, "Le residenze dei missionari," $p$. 464.

${ }^{29}$ Bugnini, La Chiesa in Iran, p. 167.

30 'Abd al-'Aziz was a patron of the arts, a keen collector of manuscripts and the owner of an extensive library. See Burton, The Bukharans, p. 277. 
named Georges Berthe, in early 1659 traveled to Khorasan in the company of Qolum Hajji. Arriving in Herat, and warned of troubles ahead, the Jesuits decided to separate from the caravan in order to pause for a while. Informed that Qolum Hajji had fallen into disgrace with his ruler and been killed, they never made it beyond Herat. ${ }^{31} \mathrm{~A}$ few years later, Fathers Johann Grueber and Heinrich Roth became the first Jesuits to travel all the way overland from China via Tibet to Iran. Yet this breakthrough did not inaugurate a regular missionary traffic across Asia.

Otherwise, success remained limited as well. Since like other missionaries the Jesuits were not allowed to proselytize among Muslims, they made only minimal gains in converting the local population. Their only success at evangelization seems to have consisted in having Muslim women come to them to have the Gospel read to their sick children and in baptizing the latter before they died. ${ }^{32}$

Nor did many Gregorian Armenians heed their invitation to follow the Roman rite. Of the ones who did, the Shahrimanians (Scerimans) were the most important. This prominent, very wealthy merchant family oversaw a trading network that spanned the eastern hemisphere. Beginning in 1646, several of its members went over to the Catholic faith, partly for reasons of expediency, having to do with their long-standing presence and multiple interests in Italy. The Shahrimanians had their own church in New Julfa. In the spring of 1691, the financial contribution of one of their leaders, Markar, made it possible for the Jesuits to enlarge their church as well. ${ }^{33}$ The Italian traveler Gemelli-Careri visited it in 1694 and found it well designed though still small, adding that it was adjoined by a beautiful garden and a vineyard. ${ }^{34}$ According to Franz Caspar Schillinger S.J., who stayed at the Jesuit convent in 1699, the Jesuit is church exceeded all others in New Julfa in luster and was the only one in town allowed to toll its bell. ${ }^{35}$ The school the Jesuits operated ran next to the church was quite successful as well.

${ }^{31}$ See Zimmel, "Bemühungen," pp. 104-106. The name Qolum Hajji for the envoy appears in Burton, Bukharans, p. 277.

${ }^{32}$ De Rhodes, Relation, pp. 39, 107, 112. Also see Richard (ed.), Raphaël du Mans, vol. 1, p. 34.

${ }^{33}$ Anon. [Chick] (ed.), Chronicle of the Carmelites, p. 460, fn.

${ }^{34}$ Gemelli-Careri, Giro del mondo, vol. 2, p. 133.

${ }^{35}$ Anon. [P. Villotte], Voyages d'un missionnaire, pp. 154-155; and Schillinger, Persianische und Ost-Indianische Reis, pp. 241-242. The ban on the tolling of church bells was a standard practice in Islamic lands. 
Schillinger informs us that it served about 100 pupils, the children of French and other European residents of Isfahan, who were taught French, Latin and Armenian. ${ }^{36}$

In the course of 1694 the leaders of Isfahan's Gregorian Armenians took advantage of the power vacuum caused by the protracted retreat of the ailing Shah Soleyman into the harem to gain the upper hand in their efforts to undermine the Catholics, the local Armenians represented by the Shahrimanians as well as the European missionaries. In the summer of that year, they began a campaign slandering both for being beholden to European Christian rulers. A petition requesting action signed by 900 persons and accompanied by lavish bribes to various officials, was presented to the queen mother, the patron of New Julfa. In response, the missionaries drew up a letter of protest, requesting compliance with their existing freedom of operation. They also demanded an end to the harassment by the Gregorian Armenians, threatening with the threat that, otherwise, they would notify the shah as well as the Christian rulers of Europe, and that the Armenians would be responsible for the consequences. Yet the Gregorians represented by the queen mother prevailed, and an order was issued for the demolition of the unfinished Carmelite church in New Julfa and the expulsion of the Carmelite from the town. Only the intervention of Ignatius Franciscus Zapolski S. J., the Polish ambassador present in Isfahan at the time, may have saved the Jesuits from a similar fate. ${ }^{37}$ As it happened, the Jesuits not only survived this crisis but the ardently anti-Catholic policy of Aleksander Julayeci, the Armenian Katolikos between 1706 and 1714, as well, and even the fall of Isfahan to the Afghans in $1722 .{ }^{38}$ Indeed, their single most important representative, the Polish Father Thaddeus Krusinski (1675-1753), only arrived in the country in $1706 .^{39}$

At least until they received support from the Shahremanians, a lack of money was a perennial problem for the Jesuits, despite some French and Polish funding. It became an even more pressing issue after the

\footnotetext{
${ }^{36}$ Schillinger, Persianische und Ost-Indianische Reis, 244.

${ }^{37}$ Anon. [Chick] (ed.), Chronicle of the Carmelites, pp. 461-469; and Kroell (ed.), Nouvelles d'Ispahan, p. 78, letter Gauderau, Isfahan, 16 Feb. 1695.

${ }^{38}$ For Julayeci and his bitter opposition to the Catholics, see Ghougassian, Emergence of the Diocese, pp. 149ff.

${ }^{39}$ Krusinski was an eyewitness to the siege and fall of Isfahan in 1722, and stayed on in Iran for another three years. For Krusinski, see Matthee, introduction to the new edition of Krusinski, History of the Late Revolutions.
} 
purchase of the house in Isfahan in 1657. In his letters, De Rhodes frequently laments a lack of funds for operating costs, expressing the hope that financial assistance might arrive, either by way of missionaries traveling to Iran or by way of checks processed through the Armenian commercial circuit and its contacts in Europe. ${ }^{40}$ Penury continued to plague the Isfahan mission long after De Rhodes's death in 1660. In 1674, Jean-Baptiste de la Maze, at that point the superior of the mission, told the Venetian visitor Ambrosio Bembo that his annual allowance did not exceed 90 reals of eight, which was sent to him from France. ${ }^{41}$

Yet this relative failure did not prevent the Jesuits from dreaming about expansion beyond the capital; in fact, the very hardship they suffered seems to have strengthened their resolve to pursue evangelization to the point of eagerly anticipating the prospect of becoming martyrs for the faith. De Rhodes is very clear about this in his Relation. Taking stock of his order's achievements in Iran and looking toward the future, he projected the need for two more colleagues, stipulating that these should above all be capable of learning the two most useful languages of the country, Persian and Armenian, as well as be versed in the sciences. He also cast his eye toward the north, indicating that Chézaud intended to move to the territory were the Ark of Noah was said to be located, at thirty days' travel from Isfahan, to create a new Jesuit outpost. ${ }^{42}$ Chézaud never made it to the Caucasus, though, and it would be another thirty years before the Jesuits were able to realize the dream of extending their mission northward.

\section{The Jesuit Mission of Shamakhi}

The Jesuits were not the first missionary order to establish a presence in the Caucasus. The Christian territories of Georgia and Armenia had long maintained relations with European men of the cloth. Dominican and Franciscan missionaries had resided in Georgia as of the thirteenth century, and Tiflis (Tbilisi) had become a Catholic See in 1328.

${ }^{40}$ Zimmel, "Vorgeschichte und Gründung," p. 24.

${ }^{41}$ See Bembo, Travels, p. 358. The translator, following Bembo's orthography, mistakenly calls Mercier "Merce," and De la Maze, "Lamasia."

${ }^{42}$ De Rhodes, Relation, pp. 103, 108. 
Following the arrival of the Augustinians in Iran in 1604, Kakhet ' $i$, the central region of Georgia, was home to a short-lived Augustinian mission between 1608 and 1611. Armenian rulers, seeking help against the eastward expansion of the Ottomans, in 1549 sent a delegation to Rome with an offer to submit to papal authority. ${ }^{43}$ The same fears of the Turks in 1604 initially caused the Armenians to welcome Shah 'Abbas's army invading their homeland as a liberating force. When the Safavid campaign turned into a violence-ridden power grab, the Armenians soured on the Iranians and turned to Europe for assistance, enthusiastically looking forward to the arrival of Christian missionaries. In reacting to a similar campaign against their territory involving mass destruction, massacres and deportation, the Georgians, too, reached out to Rome, seeking a revival of the Crusader spirit and requesting the dispatch of missionaries. ${ }^{44}$ In 1626 the pope responded by sending the Italian Theatines to Georgia. These would maintain a mission in Gori until the 1640s. ${ }^{45}$ The Capuchins were represented in Tbilisi as of 1661, established a chapel in Yerevan in 1667, and in the late seventeenth century had a presence in Gori, Ganja and Shamakhi as well.

The founding of the Jesuit mission of Shamakhi, located some 100 $\mathrm{km}$ west of Baku, in the current Republic of Azerbaijan, took place while Shah Solayman (r. 1666-94) occupied the Safavid throne. In some ways, his reign was not the most propitious time for Christians in Iran. Mounting economic problems put a growing fiscal strain on the country, and religious minorities, above all the prosperous Julfan Armenians, proved an easy target for the growing need for royal revenue. At times, Christians, like all non-Shi is inhabitants, also suffered from clerically induced harassment. Nor were the missionaries spared. During the long tenure as grand vizier of the fastidious Shaykh 'Ali Khan (1669-89), who among foreigners became known as a "sworn enemy of the Christians," many in the Safavid establishment eyed their presence and activities with suspicion. ${ }^{46}$ The collusion between the elders of the Gregorian Armenian community and various Safavid state

${ }^{43}$ Johanissian, Israel Ory, pp. 24-31.

${ }^{44}$ See Alonso, "Una embajada de Theimuraz."

${ }^{45}$ Flannery, Mission of the Portuguese Augustinians, 213-215; and the series of articles on the Theatines in the Caucasus by Carlos Alonso, "Documentación inedita."

${ }^{46}$ For Shaykh 'Ali Khan and his role as Safavid grand vizier, see Matthee, "Administrative Stability and Change." 
officials, including the queen mother, continued to make their life difficult as well.

Yet, like most Safavid rulers, Shah Solayman harbored no personal animosity vis-à-vis Christians, including foreign missionaries. Although he is said not to have displayed the "same interest in Christians as his father,." ${ }^{47}$ Yet he shah occasionally visited the Armenian All Saviour's Cathedral in New Julfa, and he followed his forebears by issuing many multiple decrees confirming the rights of Armenians residing in the Caucasus or prohibiting Muslims from maltreating them. ${ }^{48}$ In keeping with tradition, this qualified benevolence was part toleration, part calculation. It was informed by the Islamic code that offered the "People of the Book" or dhimmis protection in return for limited rights and higher taxes, but also colored by an awareness of the usefulness of Armenians on account of the many commercial and political links they maintained with Europe. ${ }^{49}$

There can be little doubt that the shah's decision in 1685 to grant Christian missionaries permission to set up a mission in Shamakhi was in part based on a perceived political dividend. The authorization, after all, coincided with a resurgence of the "Turkish" question caused by a renewed Ottoman offensive into the heart of Europe, culminating in their siege of Vienna in the same year. Polish involvement in the initiative is unsurprising. Poland after all played a decisive role in the confrontation at Vienna in 1683, heading the Christian coalition that halted this latest Turkish advance by breaking the siege of the city. The Poles also had conducted an active Iran policy for decades. Their most prominent representative in the period under discussion is Bogdan Gurdziecki, a Georgian who first came to Isfahan in 1669-70 to negotiate a commercial agreement on behalf of the Polish and Russian governments. Held up on his return journey by the Sten'ka Razin revolt that had broken out in Astrakhan, he ended up spending three years in Shamakhi before returning to Poland in 1675. The recorded show that he returned to Iran in 1681-82 as the head of a Polish mission. Shah Solayman initially offered him the position of kalantar of Nakhchevan and five or six surrounding Catholic villages, but when he refused to

${ }^{47}$ Bedik, A Man of Two Worlds, p. 232.

${ }^{48}$ Landau, "European Religious Iconography," p. 425; and Simēon of Erevan, Jambr, pp. 342-347.

${ }^{49}$ For this, see Matthee, The Politics of Trade in Safavid Iran, pp. 193-197. 
convert to Islam, a condition for the appointment, he was allowed to become the permanent Polish representative in Shamakhi. He left for Shirvan in February 1682. Unfortunately nothing more is know about his further activities other than that he seems to have remained in Iran until 1699. ${ }^{50}$

Rather than to Gurdziecki, the Shamakhi mission owed its creation to an initiative, mediated by the Roman Propaganda Fide, of Count Constantin Salomon Siryri Zagórski, emissary extraordinaire of the Polish King Jan III Sobieski (r. 1674-96). ${ }^{51}$ Count Zagórski was sent to Isfahan carrying a letter from the Polish crown in behalf of the Christians of Nakhchevan who had long suffered under a series of oppressive governors. After his arrival in the Safavid capital, he is said to have used all his credit with Shah Solayman to receive permission to establish the outpost in Shamakhi. ${ }^{52}$

There are several reasons why Shamakhi was chosen as the site of the next Jesuit mission in Safavid territory. One was its strategic location on the road from Iran to Russia and Poland. ${ }^{53}$ Another was its cosmopolitan character. The town was home to multiple nations, from Shi $i$ and Sunni Iranians and Turks to Russians; and, most importantly, it housed a sizeable Armenian community. It was apparently a segment of this Armenian community, and in particular Martiros, the bishop of St Stephan in Shamakhi, who approached ZgórskiZagorski, who was familiar with Shamakhi as a halting place in the Caucasus, en route to Isfahan, expressing an interest in having a Christian mission in their midst, presumably from a desire to draw closer to the Church of Rome. In 1683, en route to Isfahan, Zgórski e turned to the prefect of the small Capuchin mission in town, P. Gioseppe, and together they approached the Vatican for assistance. ${ }^{54}$ The authorities in Rome, no doubt eager to capitalize on the newly awakened Crusading fervor, responded eagerly, and as a result Pope Innocent XI in August 1684 addressed a letter to the Safavid ruler with the following content:

\footnotetext{
${ }^{50}$ Nationaal Archief (NA), The Hague, VOC 1379, Casembroot, Isfahan to Batavia, 6 March 1682, fols. 2663r-64r; Zedgnidze, "Iz istorii pol'skikh-russkikh diplomaticheskikh otnoshenii," pp. 12-20; and Zevakin "Persiskii vopros," pp. 145-146.

${ }^{51}$ For Zgórsky, see Stopka, "Salomon Syri Zgórski." Thanks to Natalia Królikowska for bringing this source to my attention.

${ }^{52}$ Avril, Voyages, p. 70.

${ }^{53}$ Anon. [De la Maze], "Mémoire de la province de Sirvan," p. 44.

${ }^{54}$ Eszer, "Missionen in Randzonen," pp. 675-678.
} 
[...] Since it has become known to us that the envoys of Christian princes, sent by those same princes to Your highness, on the road by which they make for Your court in all cases touch at Shamakha which is reckoned among the chief towns of Your famous country and lying on that same route, We are easily induced to solicit of the courtesy by which You are particularly distinguished above the other eminent qualities of Your royal mind, that You will permit a dwelling to begot ready there for the reception of Christians who proceed to Your vast dominions... ${ }^{55}$

Shah Soleyman's response to this request, contained in a letter to the Roman pontiff written sometime in 1685 , has been preserved as well. In it the shah gives permission for the construction of "buildings in the district of Shirwan for the habitation of passers-by from your royal realm." ${ }^{56}$

The French Father Pothier, who had arrived in Iran in October 1683 carrying letters and presents from Louis XIV, was to be the first prior of the new mission. ${ }^{57}$ Count ZgórskiZagorski, determined to be present at its inauguration, accompanied Pothier to Shamakhi. Arriving in July 1686, he left the latter there while he himself went on to travel to Poland to report to King Jan III Sobieski on the negotiations he had conduced in Isfahan on behalf of all the Christian powers engaged in war against the Turks. ${ }^{58}$

Having established himself in Shamakhi, Pothier is said to have ingratiated himself with the local community with his charm and his "edifying conversation." Yet a little over a year after his arrival, on 27 September 1687, he was assassinated, or martyred in the rendering of his fellow Jesuits, following a dispute with the owner of the house he had rented in town, a "Turk" (Muslim) who, furious that his house had become a temple of the house of the Christian God, had broken into his room and knifed him to death. ${ }^{59}$

${ }_{55}^{55}$ Anon. [Chick], (ed.), Chronicle of the Carmelites, p. 424.

${ }^{56}$ Ibid.

${ }^{57}$ Pothier had arrived in Isfahan in the company of Père Longeau, another French Jesuit. Both had initially been given permission to set up a mission in Yerevan. See Anon. [Monier], "Mémoire de la mission d'Erivan," pp. 339-341.

${ }^{58}$ Anon. [De la Maze], "Mémoire de la province de Sirvan," pp. 44-48.

${ }^{59}$ Avril, Voyages, p. 71. According to De la Maze, "Mémoire de la province de Sirvan," pp. 46-48, Muslims, angry at the success of the mission, had accused the owner of the house who had sold it to Pothier of harboring Christians, after which the owner had killed Pothier. 
Following Pothier's death, the Shamakhi mission remained vacant for one year. Its next superior became the aforementioned Jean-Baptiste de la Maze, a French Jesuit who had served as head of the Isfahan mission since $1674 .{ }^{60}$

We know more about De la Maze than about Pothier. Born on 21 February 1624, De la Maze was admitted to the Jesuit order on 76 September 1640, and he offered his vows on 8 December 1658. Having taught grammar, the humanities and philosophy in France for ten years, he left for the Middle East in 1662 to serve its Jesuit mission. After spending two years in Syria, he traveled to Iran in 1664 . He would reside in the country for more than forty-five years, of which more than twenty in Shamakhi, and he died in the latter city, aged 87, on 4 March 1709.61

The town De la Maze headed for in 1687, armed with a royal commandment, raqam, from Shah Solayman, derived its importance from its function as a regional center in the fertile region of Shirvan, and as a way station on the commercial route connecting Iran with Russia via the Caucasus. Its location in the foothills of the Elburz Mountains shielded it and its immediate surroundings from the warfare and depredations that were endemic in the lowlands. Further security was provided by the Safavid government, which by disbursing an annual sum of 700 tumans to the shamkhal, the ruler of the tribal Lezghis inhabiting the region, bought insurance against the raiding activities of the latter. ${ }^{62}$

In 1647 the Ottoman traveler Evliya Chelebi described Shamakhi as a city of some 7,000 houses, a pleasant place filled with forty-four caravanserais, numerous mosques, Sufi lodges, and coffeehouses. ${ }^{63}$ Two decades later, in November 1667, a terrible earthquake leveled two-thirds of the town, destroying 5,000 to 6,000 houses, and burying an estimated 20,000 people under the rubble. ${ }^{64}$ The town was rebuilt,

${ }^{60}$ Like his fellow Jesuits active in Iran at the time, De la Maze is not mentioned in O’Neill Dominguez, Diccionario histórico de la Compañia de Jesús.

${ }^{61}$ Archives des Jesuites de Paris, Perse, nr. 30, "Jean Baptiste de la Maze." The dates given in Pradel de Lamase, "La religion Chrétienne en Perse," are slightly different.

${ }^{62}$ Anon. [De la Maze], "Mémoire de la province de Sirvan," p. 28; Krusinski, History of the Late Revolutions, vol. 1, p. 243.

${ }^{63}$ Chelebi, Travels, p. 80.

${ }^{64}$ Avril, Voyages, p. 69; Chardin, Voyages, vol. 10, pp. 81-82. 
although following its reconstruction it did not boast any noteworthy public building or a major mosque. Trade revived very quickly as well, and by the 1680s Shamakhi once again was a thriving commercial center and one of the most populous and cosmopolitan towns of Iran. The Muscovites had their caravanserai in town, which they supplied with tin, copper, leather, sable skins, and other merchandise, while the Iranians and Indians brought a large volume of raw silk, which they sold, in addition to cotton textiles, and gold and silver brocade. The Tatars brought horse and slaves. At that time the city again counted some 50,000 inhabitants. According to Philippe Avril, no urban center in the realm of the shah housed as many foreign residents, Indians, Muscovites, Georgians, Greeks, Turks, Circassians and many others. ${ }^{65}$ Muslims, divided into mutually antagonistic Sunnis and Shi is, were in the majority. The Jews had their own synagogue; the Indians, who numbered some 200 and were the richest merchants in town, worshipped in their own temple. The local Armenians were the main representatives of Christianity. Their bishop usually resided in a monastery located in the surrounding countryside. The Muscovites had their own Orthodox chapel, which was located in their caravanserai. ${ }^{66}$

During his twenty-two years in Shamakhi, De la Maze primarily served the town's Christian merchant community, saying mass each day and offering the Sunday sermon in Turkish - the dominant language in the town and the surrounding region. Soon after his arrival, another Jesuit, Father Franciscus Xavier Champion, arrived from France to help him administer the mission. Champion was young and energetic and had studied medicine, giving him a skill that proved extremely useful since it opened any and all doors to the priests. ${ }^{67}$ The Jesuit Father Jacques Villotte, who arrived in Shamakhi in May 1689, attests to De la Maze's religious zeal with a story about how he went out to visit a caravan which, en route to Astrakhan, halted for a few days at a location near Shamakhi. He set up an ad-hoc mission and made such an impression on the merchants that they invited him to ac-

${ }^{65}$ Avril, Voyages, p. 69. Avril's assertion that Shamakhi's Armenian population numbered 30,000 (out of a total of c. 50,000) must be a mistake. The correct number may have been 3,000. De la Maze mentions 200 Armenian houses. See Anon. [De la Maze], "Mémoire de la province de Sirvan."

${ }^{66}$ Ibid., pp. 26-27.

${ }^{67}$ Anon. [De la Maze] "Mémoire de la province de Sirvan," p. 40. 
company them to Nizovoi, the harbor on the Caspian Sea where merchandise brought from Iran and destined for Russia was usually loaded on ships setting sail for Astrakhan. He declined the offer with the excuse that he could not leave one of his colleagues in Shamakhi who had just arrived. ${ }^{68}$

De la Maze was exceptional although not unique among missionaries in Iran in his linguistic abilities, giving the lie to Jean Chardin's sneer that the Christian missionaries in Safavid territory stood out for their inability to speak Persian. ${ }^{69} \mathrm{He}$ almost certainly knew Persian well. As said, he was fluent in Turkish. And the Frenchman Petis de la Croix, who saw him occasionally in New Julfa in the mid-1670s, informs us that De la Maze offered to teach him Armenian, which he knew so well, Petis de la Croix claimed, that he lectured young Armenians in that language, succeeding in "converting several of them to our religion." 70

Thanks to observations by visitors as well as letter and reports from his own hand, we have some additional information about De la Maze's life and activities in Shamakhi. The Dutch traveler Cornelis de Bruyn, who in 1702 spent some time in Shamakhi on his way down from Russia and who again visited the town in 1707 on his return journey, does not call him by name but clearly refers to De la Maze when he mentions the superior of the local Jesuit mission. He speaks highly of De la Maze, mentioning that he would visit him daily and that he voiced his concern for De Bruyn's personal safety in the dangerous environment of the town. ${ }^{71}$

An undated letter written by De la Maze, which can nevertheless be dated to 1693 or 1694 because it refers to Pothier's death as having happened six to seven years earlier, offers much interesting information about the Jesuit outposts in the Caucasus, including the ones at Ganja and Yerevan, which had come into being in the same period as Shamakhi. We learn from it that the various missions stayed in touch with each other through intermittent correspondence and fairly regular mutual visits. Also noteworthy is that missions were often just occupied

${ }^{68}$ [Villotte], Voyages d'un missionnaire, 92.

${ }^{69}$ Chardin, Voyages, vol. 6, pp. 154-157; and vol. 7, p. 436.

${ }^{70}$ Petis de la Croix, Extrait du journal, p. 127; and [Villotte], Voyages d'un missionnaire, pp. 92-96.

${ }^{71}$ De Bruyn, Reizen over Moskovie door Persie, p. 435. 
by one single friar, resulting in a great deal of loneliness. Pothier died alone, De la Maze notes, as did Roche in Erzurum, murdered by a servant, after he had written to De la Maze that he was by himself and feared dying alone from the plague without being able to say the final confession to a fellow Jesuit. Fathers Longeau, Roux, and Du Puys, too, had died all alone in Yerevan. De la Maze was all by himself, too, after Fathers Villotte and Balée had left him to go to Isfahan. He also mentions a Father Jan Gostkowski, who had departed for Mingrelia in western Georgia. As for Zapolski, he had stayed as briefly as he could, spending most of his time in the countryside; and he had eventually given up his post in Shamakhi to become ambassador (again). And now, with the departure of [an otherwise unknown] Father Sousastre, De la Maze was left all by himself, without a confessor. Precisely the inconstancy and the inconveniences suffered by the missionaries had caused the Jesuits to leave their missions, he asserts. Father Vandernandre had left the mission of Yerevan and was said to have gone to Greece. Father Maldaut had abandoned his post in Erzurum, located in Ottoman territory, to return to France. Father Portier had been forced to go back to Europe on account of his poor health. Father Sousastre, finally, De la Maze laments, had left him four or five months earlier without orders and for no other reason than that he had the impression that his superiors wanted him to stay on rather than allowing him to go to China. ${ }^{72}$

A great deal of financial disappointment and frustration comes through in the same letter as well. The Shamakhi mission suffered from a chronic lack of money. Since the Jesuit mission in Iran formally fell under the jurisdiction of the Polish crown, some money clearly came from Warsaw. Before setting out for Iran as Polish ambassador in 1691, the aforementioned Jesuit Zapolski received from his patron, King Jan III Sobieski, alms in the amount of 1,000 Polish florins, enabling de la Maze to purchase land for the construction of the residence in Shamakhi. ${ }^{73}$ It is likely that the Shamakhi mission continued to be sponsored by the French monarchy, and perhaps by the Propaganda Fide, as well. It is just as likely that the subsidy was minimal, though. The situation in Shamakhi was probably similar to what Schillinger,

\footnotetext{
${ }^{72}$ Archivum Romanum Societatis Iesu (ARSI), Rome Gall. 97"II 225 , letter De la Maze, n.d.

${ }^{73}$ Krzyszkowski, “Entre Varsovie et Ispahan,” p. 102.
} 
visiting Yerevan in 1699, said of the three Jesuit fathers in that town. These received a small annual allowance of 150 livres, equaling some 3 tumans, courtesy of unnamed French consuls. Since this sum - equal to the annual wages of a manual laborer in late seventeenth-century Iran-was not enough to cover living expenses, the fathers lived off the produce of their own garden and also cultivated grapes, selling the wine these yielded. ${ }^{74}$ De la Maze finally blamed the prevailing penury in part on all the trips undertaken by various missionaries. These, he laments, cost a great deal of money, which could have been much better spent clothing and feeding the missionaries. Why, he wonders, would the Jesuit order want to maintain missions if it could not properly sustain them; and why, given the charity used to minister to the sick and the dying in Europe, would one allow five Jesuits fathers to end their lives without receiving the sacraments.

De la Maze himself did little long-distance traveling, or so it seems. He only appears to have returned to Isfahan once in the more than two decades that he resided in Shamakhi. The context of his journey, which he undertook in 1698, was the mission of M. Zubarek, a Catholic Armenian from Shamakhi, to the court of Poland, where he had been sent by Shah Soltan Hosayn (r. 1694-1722) to congratulate the new Polish King, Augustus II, with his ascent to the throne in 1697. Sent back as the representative of the Polish crown tasked to convey the greetings of the King to the Shah, Zubarek thought it judicious to have a fellow Catholic on his side and thus requested the company of De la Maze, who gladly complied, despite his 73 years. The travelogue that De la Maze wrote on the basis of their journey is filled with interesting information about various aspects of life in the countryside they passed through. ${ }^{75}$ The archives of the Jesuit Order in Rome also contain a lengthy manuscript from the hand of De la Maze, in which he gives a detailed description of the region of Shirvan. ${ }^{76}$

Like his colleagues, De la Maze almost certainly became involved in the ongoing quarrel between the Gregorian and Catholic Armenians. We only have indirect information about this, though. A letter from 1711 from Yerevan talks about the persecution of the mission of Ganja

${ }^{74}$ Schillinger, Persianische und Ost-Indianische Reis, pp. 118-119. For wages and the cost of living in Safavid Iran, see Siebertz: Preise, Löhne und Lebensstandard.

${ }^{75}$ De la Maze, "Journal du voyage du Père de la Maze."

${ }^{76}$ ARSI, Gall. 97"I, no title (description of journey through northern Iran, in French). 
as being no less severe than that suffered by other missions in the region, despite the fact that a new Polish ambassador had visited. The school in Ganja had been closed and the pupils chased out, and two Catholics who used to visit the church had been imprisoned. ${ }^{77}$ In 1718 the Gregorian Armenians, acting at the instigation of their Katolikos, destroyed the Capuchin missions of Tiflis and Ganja. ${ }^{78}$

As was true of other towns in the southern Caucasus, the Muslims of Shamakhi often treated their fellow Christians rather poorly. A letter De la Maze wrote from Shamakhi on 1 September 1702 makes clear that the Armenians in town suffered many vexations from the local Muslims, which included various unreasonable taxes going beyond the customary yizya, poll tax, imposed on them. ${ }^{79}$ De Bruyn, visiting in 1707, confirms the gravity of the situation, indeed suggests that matters had worsened over time by reporting how the Jesuit fathers of Shamakhi were subject to harassment by members of the local population who would break into their convent and threaten them on an almost daily basis. He blamed this on the current governor, whose rule was a far cry from that of his father, Allah Verdi Khan, who had governed the town during De Bruyn's visit five years earlier, and who had dispensed justice while maintaining law and order. The son, by contrast, De Bruyn insisted, was incompetent as well as undisciplined, and much given to drinking, which he justified by arguing that the shah had given people permission to consume wine, as a result of which many of the local inhabitants would drink to excess and engage in rowdy behavior. De Bruyn, referring to deteriorating political and economic conditions in Iran at the time, also claimed that local soldiers often did not receive their pay on time, causing them to engage in violence against the civilian population. ${ }^{80}$

Following de la Maze's death, his assistant, Champion, appears to have assumed responsibility for the mission of Shamakhi. At a later date, presumably after Champion's death, Père Bachoud took over, as-

${ }^{77}$ Archives des Missions Etrangères (AME), Paris, vol. 354, letter Gatien de Galliczon, Evêque d'Agatophefrom the Archbishop of Agatophe, Yerevan, 18 Oct. 1711, fol. 374; and Archives Nationales de France, Coll. F5A/26, letter Gatien de Galliczon, Evêque d'Agatophe, Miana, 15 Dec. 1711, fol. 30.

${ }^{78}$ Anon. [Chick] (ed.), Chronicle of the Carmelites, p. 553.

${ }^{79}$ De la Maze, Shamakhi, to P. Emiliani, mission of Moscow, 1 Sept. 1702, This letter was published in Pis'ma i doneseniia Iezuitov, pp. 296-297.

${ }^{80}$ De Bruyn, Reizen over Moskovie door Persie, p. 434. 
sisted by a Père Richard. We have very little information about the mission's fate in the subsequent period. Letters written by Bishop Gatien de Galliczon in late 1711 from Yerevan and Miana talk about the persecution of the mission of Ganja as being no less severe than that suffered by other missions in the region, despite the fact that a new Polish ambassador had visited. The school in Ganja had been closed and the pupils had been chased out, and two Catholics who used to visit the church had been imprisoned. The Capuchin mission of Tabriz had been forced to close as well, as had the mission of Shamakhi, its members beaten or forced to flee.$^{81} \mathrm{In}$ all cases, closure seems to have been temporary, though, for we do have documentation about all three missions for subsequent years.

Even if the various branches of the mission in the Caucasus managed to reopen, their Its precarious financial conditions only seem to have worsened as the so-called Great Northern War (1700-21) and internal divisions proved to be ruinous for Poland, the source of much of the support. Polish ecclesiastical authorities had long expressed little faith in the missions in the Caucasus they oversaw, considering them little effective and indeed rather useless. ${ }^{82}$ In the early eighteenth century their lack of success more than once caused the supervisors to contemplate terminating these outposts. Thus in 1715 the council of the Polish Jesuit Province decided to close its mission in Iran; the Jesuit Provincial Superior in Poland, Reinhold Gert, wrote to the order's Superior General in Rome, Michelangelo Tamburini, that the Iranian mission should be terminated, since there were more missionaries than Catholics in the realm of the shah. Tamburini did not agree with Gert and the mission was allowed to continue; yet the threat of closure hardly boded well for its survival. ${ }^{83}$

We have no information about continued French (or Polish) support for the Shamakhi mission, but local conditions in Shamakhi at this

${ }^{81}$ Archives des Missions Etrangères (AME), Paris, vol. 354, letter Gatien de Galliczon, Evêque d'Agatophe, Yerevan, 18 Oct. 1711, fol. 374; and Archives Nationales de France, Coll. F5A/26, letter Gatien de Galliczon, Evêque d'Agatophe, Miana, 15 Dec. 1711, fol. 30.

${ }^{82}$ Krzyszkowski, "Entre Varsovie et Ispahan,” p. 116.

${ }^{83}$ Brzezińskí, Misjonarze i dyplomaci polscy, pp. 148-149. In reality there were only seventy missionaries in Iran at the time, only four of whom were Jesuits. And there were thousands of Catholic Armenians living in Safavid-controlled Armenia. See Kostikyian, "European Catholic Missionary Propaganda," p. 374; and Bedik, A Man of Two Worlds, pp. 409-435. 
point did little to improve matters. As the Safavid state, ruled by a superstitious, reclusive shah, grew weaker, its grip on outlying provinces loosened. This inevitably gave rise to the kind of misrule and oppression on the margins of the Safavid state outlying provinces that De Bruyn refers to. In 1718 the Gregorian Armenians, acting at the instigation of their Katolikos, destroyed the Capuchin missions of Tiflis and Ganja ${ }^{84}$ The authorities in Isfahan meanwhile, increasingly influenced by doctrinaire members of the Shi i clergy, intensified their discriminatory practices vis-à-vis Iran's non-Shi 'i inhabitants. The result was growing alienation among the latter, leading to restiveness and revolt on the part of those who had the means to fight back, the tribal, fervently Sunni Lezghis, who saw the tributary arrangement they had made with Shah `Abbas II neglected and unheeded.

The results were disastrous. First, the city and the region suffered terribly from an outbreak of the plague between 1716 and late 1717. John Bell, who visited Shirvan in that period, claimed that the epidemic had carried off c. 70,000 people. Père Richard was among the victims, leaving only Father Bachoud to tend to the mission. ${ }^{85}$

Matters turned even more serious in 1720. In January of that year the Lezghis mounted an attack on the province of Shirvan, plundering several villages in the vicinity of Shamakhi. ${ }^{86}$ Later that same year reportedly 40,000 Lezghi tribesmen assaulted the city itself, and plundered it, targeting the town's two Indian caravanserais, until the inhabitants forced the assailants to withdraw. ${ }^{87}$ Rumor had it that this unrest had been instigated by Fath `Ali Khan Daghestani, the Safavid grand vizier of overtly Sunni beliefs who, frustrated at the increasingly intolerant Shi i tendencies of the court, stirred up trouble among his fellow Lezghis as part of an alleged scheme to overthrow the shah and become ruler himself. It would be more than two years before the Safavid-appointed vali, viceroy, of Georgia was able to retake Shamakhi. ${ }^{88}$ His army of 15,000 arrived before the city on August 15,

${ }^{84}$ Anon. [Chick] (ed.), Chronicle of the Carmelites, p. 553.

${ }^{85}$ Bell of Antermony, Travels from St. Petersburgh, vol. 2 pp. 138-139.

${ }^{86}$ Archives du Ministère des Affaires Etrangères (AMAE), Paris, AEP 5, Padery, Shamakhi, 5 Jan. 1720, 1720, fols. 258-260.

${ }^{87}$ AMAE, AEP 5, Padery, Qazvin to Paris, 31 Oct. 1720, fol. 316v.

${ }^{88}$ AMAE, AEP 6, Gardane, Shamakhi to Paris, 16 June 1722, fols. 192-193; and Bakikhanov, Heavenly Rose Garden, p. 113. 
1721. Assisted by their fellow-Sunnis inside the city, they entered Shamakhi and set out to kill anyone who opposed them. They brutally cut down the governor and several members of his family. The Jesuits, huddled together in their chapel, feared the worst, but as it turned out, the Lezghis mostly targeted Shi is, massacring between 4,000 and 5,000 . From the homes of Christians they only took whatever valuables they could gather, leaving the inhabitants alone. They broke in the chapel, and threatened the Jesuits, demanding that they bring out their possession. Not having found much, they left with church ornaments and vestments. ${ }^{89}$

\section{Conclusion}

Operating from Portuguese-held Goa in India, the Jesuits entered the Persian Gulf and maintained a mission on the isle of Hormuz for some twenty years in the mid-sixteenth century. Only in the 1640s did representatives of the same order return to Iran. This time they made it to the mainland, keen to open up new territory for evangelization and determined to create a relay station as part of a projected overland link between Western Europe and the Far East. Whereas the Jesuits who had lived and worked in Hormuz were all Portuguese, the ones who entered the Iranian interior in the 1640s came from France, reflecting that country's growing importance in the concert of Catholic nations at the time. Over time, and especially during the reign of the Polish King John II Casimir, himself a former Jesuit, these were joined by missionaries from Poland. Funding, too, came from France and Poland and, to a lesser extent, from the Propaganda Fide in Rome.

Having received permission to operate in the Safavid capital, the Jesuits acquired land and built a chapel in New Julfa. Their erudition and their willingness to engage in disputation about philosophical and religious topics with Iranian officials and clerics gave them a certain standing at the Safavid court. Yet they faced many obstacles in their attempt to build a flourishing mission, and not just because, in typical fashion, Muslims showed no interest in conversion or because they labored under perpetual financial constraint, depending on small subventions from various sources that barely covered basic expenses.

${ }^{89}$ Bachoud, "Lettre du Père Bachoud," pp. $91 \mathrm{ff}$. 
Like all missionaries, the Jesuits faced hostility from members of the increasingly influential and outspoken high Shi 'i clergy, who saw them as interlopers and who were inherently suspicious of their methods and aims. They also met formidable opponents in Iran's Gregorian Armenians, a group with considerable political clout whose leaders went to great length to thwart what they saw as missionary meddling in their ranks. In some ways the Jesuits themselves contributed to the tense atmosphere that surrounded them and the problems they encountered. Known to be more determined in their urge to proselytize than other orders, they bred resentment among their fellow missionaries, who blamed them for upsetting the delicate religious balance in the city and the country. Similarly, they showed little respect for Iran's domestic Armenians, their main target audience.

Given the obstacles they faced, it is perhaps not surprising that Jesuits achieved far less in Safavid Iran as cultural "brokers" than their peers did in sixteenth-century China, and, to a lesser extent, in Mughal India, and that their accomplishments did not go much beyond the building of a convent in New Julfa, the establishment of a small school for Armenian children, and the conversion of moribund children of Muslim parents. The creation of a fledgling mission in the north in the $1680 \mathrm{~s}$ strengthened Iran's role as a stop on the overland missionary route to China and India, but did not fundamentally change their fortunes.

The reign of Shah Solayman and especially that of Shah Soltan Hoseyn saw an increase in pressure on religions other than Twelver Shi ism. Yet even as both monarchs increasingly deferred to the demands of hardline Shi 'i counselors and frequently gave in to the Gregorian-Armenian lobby, they also renewed the permission for the Jesuits to operate on Iranian soil originally given to them by Shah Abbas II, and even allowed them to branch out to the north by establishing missions in Ganja and Shamakhi.

This expansion into the Caucasus did not herald a new dawn for the Jesuits. Plagued by money problems and living in isolation, they continued to labor in obscurity. The retreat of the central Safavid state, unleashing the abuse of intolerant religious forces and the greed of local rulers, and ultimately the growing tribal lawlessness of the early eighteenth century, proved to be their undoing.

The glimpses we have for the period after 1722 indicate that the Jesuit mission in Iran survived the fall of Isfahan by more than three 
decades. The Jesuits continued to live and work in the city until 1755, and the last ones are said to have left Iran only five years later. ${ }^{90}$ Almost a century later, in 1852, the Scottish traveler and linguist Robert Binning reported seeing the remains of the Jesuit chapel in a garden near the town of New Julfa. ${ }^{91}$ As for the other missions, Tiflis and Ganja fell victim to the anti-Catholic fervor of the Gregorian Armenians, and it is likely that the Jesuit outposts in Shamakhi and Yerevan were swept up in the collapse of Safavid rule. ${ }^{2}$ Still, having lived through the difficult Afghan interlude, the Jesuits not just survived the even bleaker period of Nader Shah's reign (1736-47), but at that time even managed to open a new post in Rasht in Gilan. Indeed, a French Jesuit, Louis Bazin, served as Nader Shah's personal physician until the latter's assassination in $1747 .{ }^{93}$ It was not until the early 1760 s that all Jesuits had left Iran. ${ }^{94}$

\section{Bibliography}

Alonso, Carlos, "Documentación inedita sobre las misones de los Teatinos en Georgia," Regnum Dei, 122 (1996), pp. 25-117; 123 (1997), pp. 119-209.

Alonso, Carlos, "Una embajada de Theimuraz, rey georgiano, al rey Felipe IV de España y al papa Urbano XVIII (1625-1629)," La Ciudad de Dios, 218 (2005), pp. 443-494.

Alonso Roma, Eduardo Javier Alonso, "Gaspar Barzeo el hombre e sus escritos," Archivum Historicum Societatis Iesu 77 (2008), pp. 63-92.

Anon. [Jean Baptiste de la Maze], "Mémoire de la province de Sirvan," in Anon.

[Fleuriau] (ed.), Lettres édifiantes et curieuses, vol. 4, pp. 11-42.

Anon. [Léonard Monier], "Mémoire de la mission d'Erivan," in Anon. [Fleuriau] (ed.), Lettres édifiantes et curieuses, vol. 3, pp. 335-348.

Anon. [Herbert Chick] (ed.), A Chronicle of the Carmelites in Persia. The Safavids and the Papal Mission to Persia of the $17^{\text {th }}$ and $18^{\text {th }}$ Centuries, London, Spottiswood 1939; repr. I. B. Tauris, 2012, 2 vols. paginated as one.

Anon. [P. Fleuriau] (ed.), Lettres édifiantes et curieuses écrites des Missions Etrangères. Mémoires du Levant. Toulouse, Noël-Etienne Sens, new edn., 1810,8 vols.

${ }^{90}$ Anon. [Chick] (ed.), Chronicle of the Carmelites, pp. 703-705.

${ }^{91}$ Binning, Journey, vol. 2, p. 81.

${ }^{92}$ In the early eighteenth century the Yerevan mission was led by Father Léonard Monier (Mosnier). He died in 1724. See Lockhart, Fall of the Safavi Dynasty, p. 439, n.

${ }^{93}$ Richard, Catalogue des manuscrits persans, p. 43; Lockhart, Nadir Shah, pp. 310311.

${ }^{94}$ Bugnini, La Chiesa in Iran, p. 167. 
Anon. [P. Villotte], Voyages d'un missionnaire de la Compagnie de Jésus en Turquie, en Perse, en Arménie, en Arabie, \& en Barbarie, Paris, Jacques Vincent, 1730.

Avril, Philippe, Voyages en divers états d'Europe et d'Asie entrepris pour découvrir un nouveau chemin à la Chine, Paris, C. Barbin, J. Boudot, G. et L. Josse, 1692.

Père Bachoud, "Lettre du Père Bachoud, missionnaire de la Compagnie de Jésus," Shamakhi, 25 Sept. 1721, to Père Fleuriau, in Anon. [Fleuriau] (ed.), Lettres édifiantes et curieuses, vol. 4, pp. 91-100.

Bakikhanov, Abbas Qoli Aqa, The Heavenly Rose Garden. A History of Shirvan and Daghestan, trans. and ed. Willem Floor and Hasan Javadi, Washington D.C., Mage Publishers, 2009.

Bedik, Pedros, A Man of Two Worlds. Pedros Bedik in Iran 1670-1675, trans. and edited by Colette Ouahes and Willem Floor, Washington, D.C., Mage Publishers, 2014.

Bell of Antermony, John, Travels from St. Petersburgh in Russia, to Various Parts of Asia, 2 vols., Glasgow, Robert and Andrew Foulis, 1763.

Bembo, Ambrosio, The Travels and Journal of Ambrosio Bembo, trans. and edited by Clara Bargellini and Anthony Welch, Berkeley, University of California Press, 2007.

Berchet, Gugliemo (ed.), La repubblica de Venezia e la Persia, Turin, G. B. Paravia e Comp., 1865; repr. Tehran, Offset Press, 1976.

Binning, Robert B. M., Journey of Two Years' Travel in Persia, Ceylon etc., 2 vols., London, W. M. H. Allen and Co., 1857.

Burton, Audrey, The Bukharans: A Dynastic, Diplomatic and Commercial History 1550-1702, New York: St. Martin's Press, 1997.

Brzezińskí, Stanisław, "Misjonarze i dyplomaci polscy w Persji w XVII I XVIII wieku." Annales Missiologicae/Roczniki Misjologiczne, 7 (1935), pp. 89-165.

Bugnini, Annibale, La Chiesa in Iran, Rome, Edizioni Vincenziane, 1981.

Burton, Audrey, The Bukharans. A Dynastic, Diplomatic and Commercial History 1550-1702, New York, St. martin's Press, 1997.

Chardin, Jean, Les Voyages du Chevalier Chardin aux Indes, et en Iran, Paris, ed. L. Langlès, Paris, Le Normant, 1810-11, 10 vols. and atlas.

Chelebi, Evliya, Travels in Iran and the Caucasus, 1647 \&1654, trans. and ed. Hasan Javadi and Willem Floor, Washington D.C., Mage Publishers, 2010.

Clossey, Luke, Salvation and Globalization in the Early Jesuit Missions, Cambridge, Cambridge University Press, 2008.

De Bruyn, Cornelis, Reizen over Moskovie door Persie en Indie, Amsterdam, Goeree, 1714.

De la Maze, Jean-Baptiste, "Journal du voyage du Père de la Maze, de Chamakié à Ispahan, par la province du Guilan,” in Anon. [Fleuriau] (ed.), Lettres édifiantes et curieuses, 1811, vol. 4, pp. 43-90. 
El-Mudarris, Hussein I., and Oliver (ed.), Le consulat de France à Alep au XVIIe siècle. Aleppo, Ray Publishing and Science, 2009.

Eszer, Ambrosius O. P., "Giovanni Giuliani da Lucca O. P. Forschungen zu seinem Leben und zu seinen Schriften," Archivum Fratrum Predicatorum 37 (1967), pp. 353-468.

Eszer, Ambrosius O. P., "Missionen in Randzonen der Weltgeschichte: Krim, Kaukasien und Georgien," in J. Metzler, ed., Sacrae Congregationis de Propaganda Fide Memoria Rerum, 2 vols., Rome-Freiburg-Vienna, Herder, 1972, vol. I/1, 1622-1700, pp. 650-679.

Flannery, John M., The Mission of the Portuguese Augustinians to Persia and Beyond (1602-1747), Leiden: Brill Publishers, 2012.

Frost, Robert I., "The Ethiopian and the Elephant? Queen Louise Marie Gonzaga and Queenship in an Elective Monarchy, 1645-1667," The Slavonic and East European Review, 91 (2013), pp. 787-817.

Galdieri, Eugenio, "Le residenze dei missionari cattolici presso la corte Safavide: Nuovi dati sulle case de Esfahan," in G. Gnoli and L. Lanciotti, (eds.), Orientalia Iosepho Tucci Memoriae Dicata, 3 vols., Rome, 1987, vol. 2, pp. 459-474.

Ghougassian, Vazken, The Emergence of the Armenian Diocese of New Julfa in the Seventeenth Century, Atlanta: Scholars Press, 1998

Gulbenkian, Roberto, Estudios Históricos. Relações entre Portugal Arménia e Médio Oriente, Lisbon, Academia Portuguesa da História, 1995, 3 vols.

Johanissian, Aschot, Israel Ory und die Armenische Befreiungsidee, Munich, Müller, 1913.

Kostikyan, Kristine, "European Catholic Missionary Propaganda among the Armenian Population of Safavid Iran," in Willem Floor and Edmund Herzig (eds.), Iran and the World in the Safavid Age, London: I. B. Tauris, 2012, pp. 371-378.

Kroell, Anne (ed.), Nouvelles d'Ispahan 1665-1695, Paris, Société d'Histoire de l'Orient, 1979.

Krusinski, Judasz Thaddeusz, The History of the Late Revolutions in Persia, London, J. Pemberton, 1733, 2 vols.; repr. The History of the Late Revolutions of Persia. An Eyewitness Account of the Fall of the Safavid Dynasty, London: I.B. Tauris, 2016.

Krzyszkowski, Joseph, "Entre Varsovie et Ispahan. Le P. Ignace-François Zapolski S.I.," Archivum Historicum Societatis Jesu, 18, 35 (1949), pp. 85-117.

Landau, Amy S., "European Religious Iconography in Safavid Iran: Decoration and Patronage of Meydani Bet ghehem (Bethlehem of the Maydan)," in Willem Floor and Edmund Herzig (eds.), Iran and the World in the Safavid Age, London: I.B. Tauris, 2012, pp. 425-446.

Lockhart, Laurence, The Fall of the Safavi Dynasty and the Afghan Occupation of Persia, Cambridge, Cambridge University Press, 1958.

Lockhart, Laurence, Nadir Shah. A Critical Study Based Mainly on Contemporary Sources, London, Luzac \& Co., 1938. 
Matthee, Rudi, "Administrative Stability and Change in Late $17^{\text {th }}$-Century Iran: The Case of Shaykh `Ali Khan Zanganah (1669-89)," International Journal of Middle East Studies, 26 (1994), pp. 77-98.

Matthee, Rudi, "The Jesuits in Safavid Persia," Encyclopaedia Iranica, online.

Matthee, Rudi, "Mohammad Beg, Grand Vizier of Shah `Abbas II," Iranian Studies (1991), pp. 17-36.

Matthee, Rudi, Persia in Crisis: The Decline of the Safavids and the Fall of Isfahan, London: I. B. Tauris, 2012.

Matthee, Rudolph P., The Politics of Trade in Safavid Iran. Silk for Silver 16001730, Cambridge: Cambridge University Press, 1999.

O’Neill, Charles E., S.J., and Joaquin M. ${ }^{a}$ Dominguez S.J., Diccionario histórico de la Compañia de Jesús-Biográfico temático, Rome, Institutum Historicum S. I.; and Madrid, Universidad Pontifica Comillas, 2001, 4 vols.

Petis de la Croix, François, Extrait du journal du Sieur Petis, Fils, Professeur en Arabe, et secrétaire interprète entretenu en la marine renfermant tout ce qu'il a vu en fait en Orient, in Ahmad Dourry Efendy, Relation de Dourry Efendy, ambassadeur de la Porthe Otomane aupres du roy de Perse, trans. M. de Fiennes; ed. L. Langlès, Paris, 1810.

Pis'ma i doneseniia Iezuitov o Rossii kontsa XVII i nachala XVIII veka, St. Petersburg, Senatskaia tipografiia, 1904.

Pradel de Lamase, M. de, "La religion chrétienne en Perse et la mission de P. de la Maze S.J. (1625-1709)," Revue de l'Histoire des Missions, 4 (1927), pp. 251-260.

Richard, Francis, Catalogue des manuscrits persans. Bibliothèque Nationale de France. Département de manuscripts. Vol. 2, Le supplément persan, Rome, Istituto per l'Oriente C.A. Nallino \& UMR7528 Mondes iranien et indien, 2013.

Richard, Francis, "Le Père Aimé Chézaud controversiste et ses manuscrits persans," Nāmeh-ye Bahāristān, 6-7/1-2 (2005-06), pp. 474-462.

Richard, Francis (ed.), Raphaël du Mans, missionnaire en Perse, Paris, L'Harmattan, 1995, 2 vols.

Rhodes, Alexandre de, Relation de la mission de Perse de la Compagnie de Jesus establie dans le Royaume de Perse, Paris, Jean Henault, 1669.

Rigordi, Francisco, Peregrinationes Apostolica R. P. Francisco Rigordi ex Societate Jesu, Lyon,

Schillinger, Franz Caspar, Persianisch und Ost-Indianische Reis, Nuremberg, 1707.

Siebertz, Roman, Preise, Löhne und Lebensstandard im safavidischen Iran. Eine Untersuchung zu den Rechnungsbüchern Wollebrand Geleynssen de Jonghs (1641-1643), Vienna, Österreichische Akademie der Wissenschaften, 2013.

Simēon of Erevan, Kat oghikos, Jambr (Archival Chamber), trans. and ed. George A. Bournoutian, Costa Mesa, Cal., Mazda Publishers, 2009. 
Stopka, Krzysztof, "Salomon Syri Zgórski," Wiki.Ormianie, at http://www.wiki.ormianie.pl/index.php/Salomon_Syri_Zg\%C3\%B3rski

Tavernier, Jean Baptiste, Les six voyages de Jean Baptiste Tavernier...en Turquie, en Perse et aux Indes, The Hague, Henri Scheurleer, 1718.

Tokatlian, Armen, Kalantars. Les seigneurs arméniens dans la Perse safavide, Paris, Geuthner, 2009.

Vaumas, M. de, Lettres et documents du Père Joseph de Paris concernant les Missions Etrangères (1619-1638), Lyon, Impr. Express, 1942.

Vissière, Isabelle and Jean-Louis, (eds.), Lettres édifiantes et curieuses des Jésuites du Levant, Paris, Desjonquères, 2004.

Wilson, Sir Arnold, "The Mission of the Fathers of the Society of Jesus, Established in Persia by the Reverend Father Alexander of Rhodes," Bulletin of the School of Oriental and African Studies, 3 (1925), pp. 675-706.

Zedginidze, G. E., "Iz istorii pol'skikh-russkikh diplomaticheskikh otnoshenii s Iranom. Deiatel'nost Bogdana Gurdzhitskogo," Avtoreferat dissertatsii, Tiflis, 1971.

Zevakin, E. S. "Persiskii vopros v russko-evropeskikh otnosheniiakh XVII veke. Istoricheskie Zapiski 8 (1940), pp. 129-162.

Zimmel, Bruno, "Bemühungen um den Landweg nach China. Die Expedition P. Aimé Chézauds S. J. nach Chorassan 1659," Neue Zeitschrift für Missionswissenschaft, 25 (1969), pp. 102-110.

Zimmel, Bruno, "Vorgeschichte und Gründung der Jesuitenmission in Isfahan (1642-1657)," Zeitschrift für Missionswissenschaft und Religionswissenschaft, 53 (1969), pp. 1-26.

Zimmel, Bruno, "Bernhard Diestel. Ein österreichischer Missionär und Entdeckungsreisender des 17. Jahrhunderts," in Joseph Mayhofer and Walter Ritzer, eds., Festschrift Josef Stummvoll, Vienna, Verlag Brüder Hollinek in Komm., 1970, 2 vols., vol. 2, pp. 880-892.

Recibido: $13 / 03 / 2014$

Aceptado: 19/01/2015 


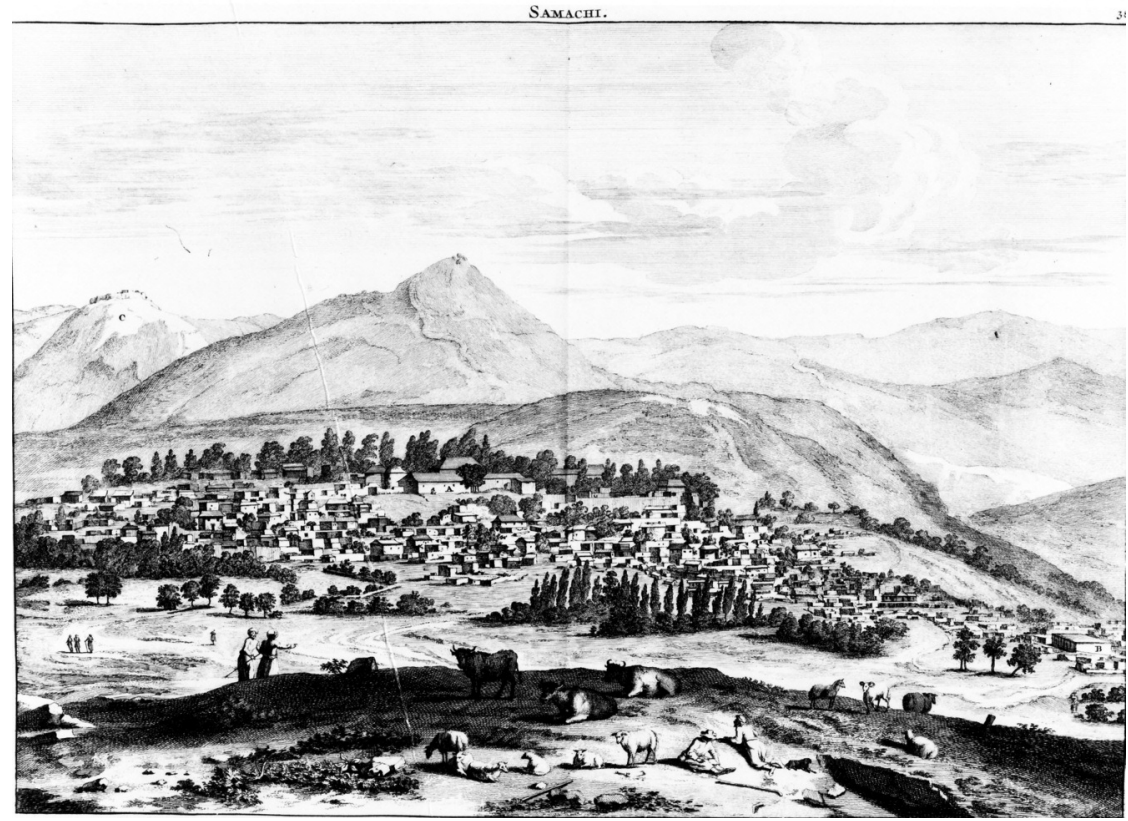

1. View of Shamakhi, 1703. Cornelis de Bruyn, Reizen over Moskovie door Persie, Amsterdam, 1714. 


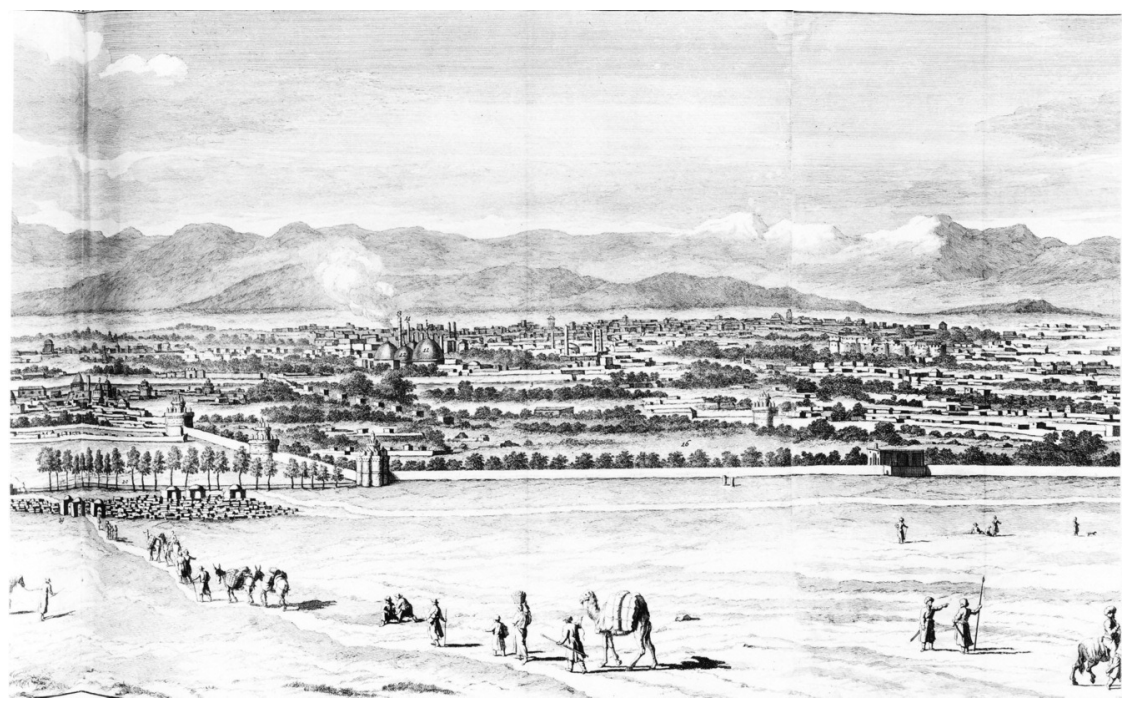

2. View of Isfahan, 1703, Cornelis de Bruyn,

*Reizen over Moskovie door Persie*, Amsterdam 1714. 


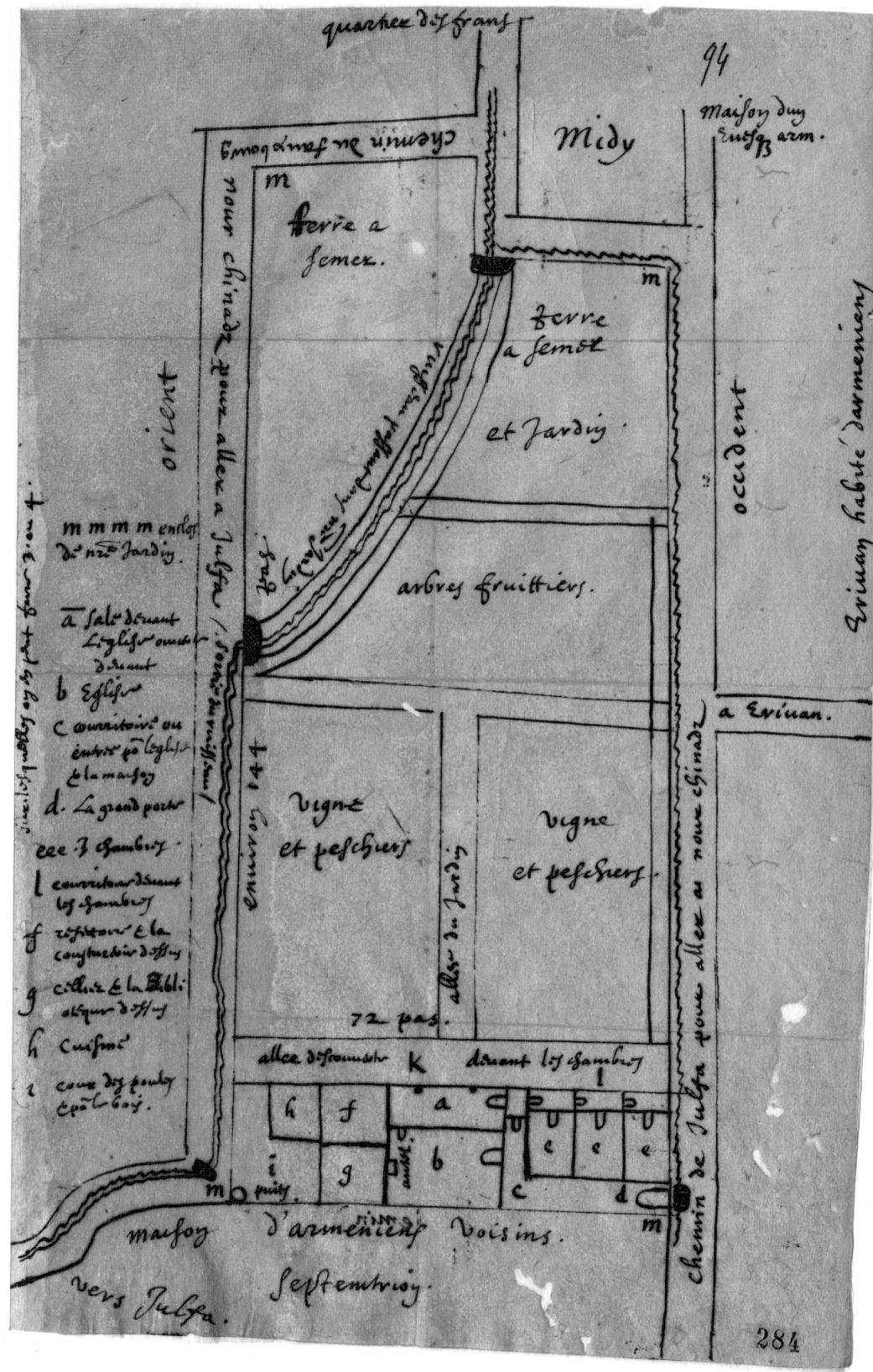

3. Floor plan of the 17th-century Jesuit mission in Isfahan ARSI Gal. 97 III f. 284. Al-Qanțara XXXVI 2, 2015, pp. 463-501 ISSN 0211-3589 doi: 10.3989/alqantara.2015.014 


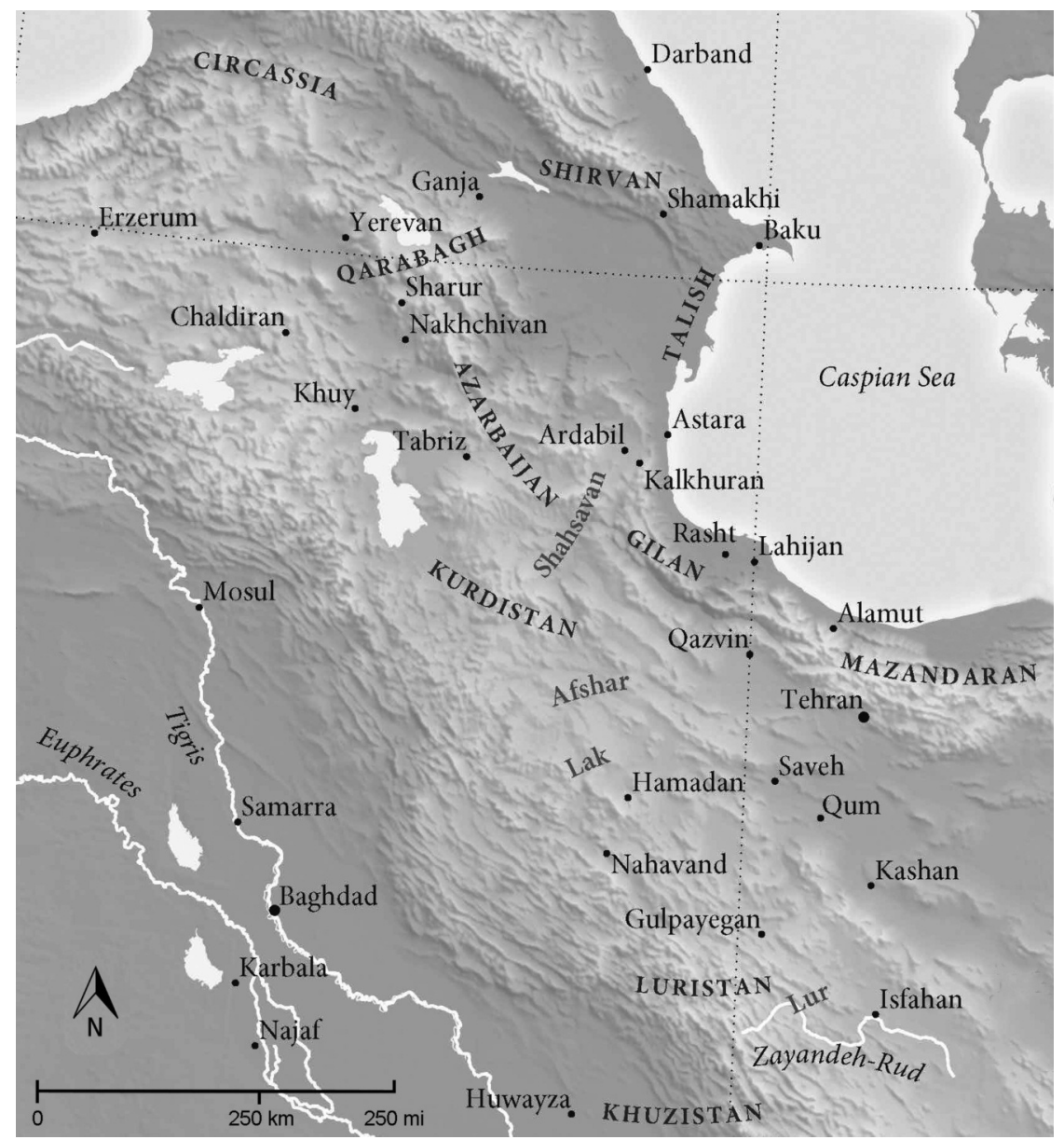

4. Northwestern Iran, Safavid period. 


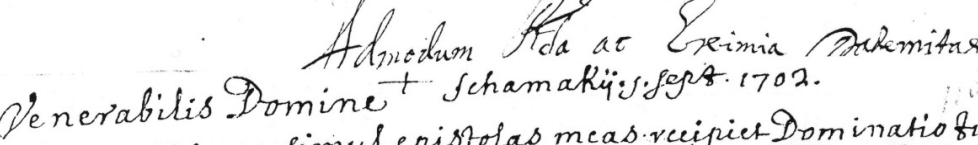

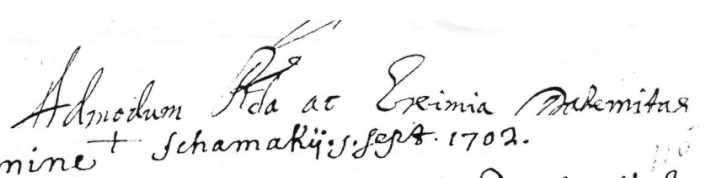
Ginas, utfiero, simul epistolas meas veipiet Dominatio fua nam Inam jam a multo kempou joannj fitio nazares dedi. Es ut awio jim ut mogkouam piter eum hom ino sarrat, qui has novas litteras tradet titi. Gonaventura catholiuns noster nuger hue costrakano s'enit, Glum putaram mify aliguaslitteras tuas -

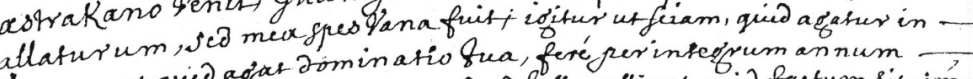

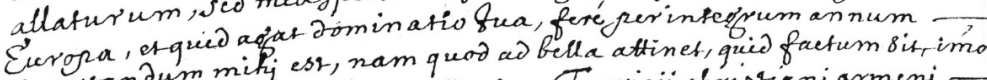
Exputanaum mity esr, namions. Tauriz $\ddot{y}$ christianj armeni

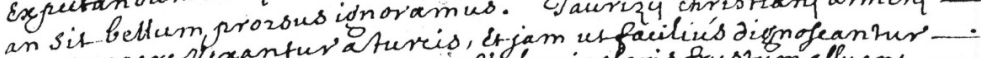

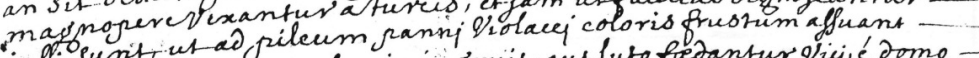

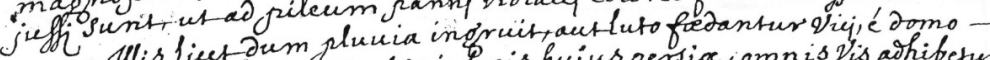

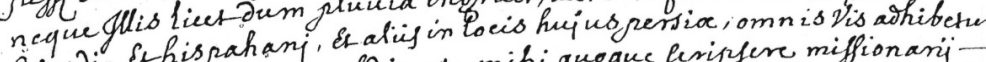
Esreji. Ethisgahanj, Et aluient. miki quoque gerigfere miffionanjut lesem christianam ab furcarum omnes nutare miffiones quio

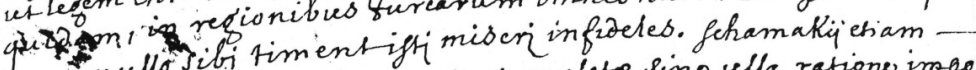
jam an ullo ir motis divexantur, muleto sino vlla ratione imgo armeny mins if rustic ita opprimunhur, utomnes fore dedeserendis. nuntur, efrent, effi tutum as itum haberent, nullus om nino oppits co istrancis mereatoribus frequentaturisallum

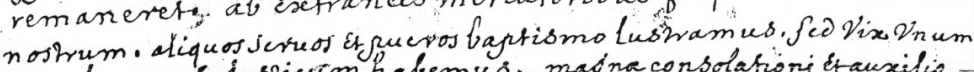
autalterum feolastictom habemus. magnaconsolation \&tauxitio nobis Effer navium Eurogioean arum conshruetio ef acceffus ad nosh

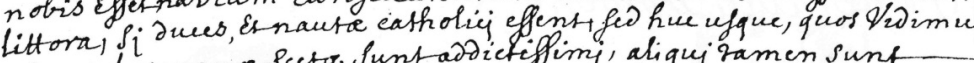
omnes turerano Secto Sunt adzicfiffiri, aliquiramen sunt fonesriffiri, Viban iffimique Vir inter hos sracipuns es 2 Jominus menerus; fo miniestrum, quem Eso in Domum noffram exeyp

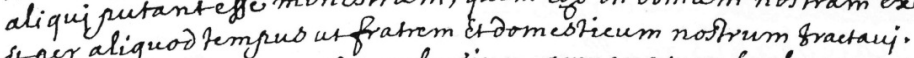
Ex mercibus! quas pos naufragium armenorum bachouenses $\partial$ ir

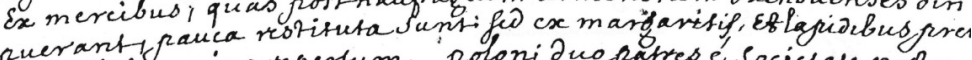

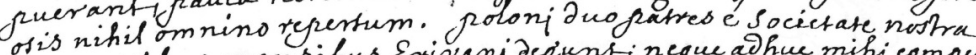
jam atribes mensibus Erivanj deginst neque al hue mificompen tupols ki mihi fugie litteras constantin opoli mithit afferingue, semp geventerum hue et nunquam appares. Domine mi perg ratum miti furis si sine ullo incom modo tuo, quoties potweris, miti aliquid feribas; nos in hoc angulo mun jilatemus, nequeponchristum aliús consolationis oenus habemus: proter amicorum per freguenses litteras consasfism. Salutemglurimam dico Venera bili socio tuo. orate pro me quofo, us teus om nia mitificecata condone orate ust

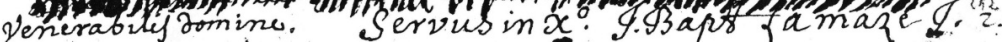

5. Letter De la Maze, Sept. 1702, G 12 Cerroniho sbírka, Moravia Regional Archives, Brno, Czech Republic. 